NBER WORKING PAPER SERIES

\title{
FERTILITY: THE ROLE OF CULTURE AND FAMILY EXPERIENCE
}

\author{
Raquel Fernández \\ Alessandra Fogli \\ Working Paper 11569 \\ http://www.nber.org/papers/w11569
}

\section{NATIONAL BUREAU OF ECONOMIC RESEARCH \\ 1050 Massachusetts Avenue \\ Cambridge, MA 02138 \\ August 2005}

The views expressed herein are those of the author(s) and do not necessarily reflect the views of the National Bureau of Economic Research.

(C2005 by Raquel Fernández and Alessandra Fogli. All rights reserved. Short sections of text, not to exceed two paragraphs, may be quoted without explicit permission provided that full credit, including (C) notice, is given to the source. 
Fertility: The Role of Culture and Family Experience

Raquel Fernández and Alessandra Fogli

NBER Working Paper No. 11569

August 2005

JEL No. J13, J16, Z10

\section{$\underline{\text { ABSTRACT }}$}

This paper attempts to disentangle the direct effects of experience from those of culture in determining fertility. We use the GSS to examine the fertility of women born in the US but from different ethnic backgrounds. We take lagged values of the total fertility rate in the woman's country of ancestry as the cultural proxy and use the woman's number of siblings to capture her direct family experience. We find that both variables are significant determinants of fertility, even after controlling for several individual and family-level characteristics.

Raquel Fernández

New York University

Department of Economics

269 Mercer

New York, NY 10003

and NBER

raquel.fernandez@nyu.edu

Alessandra Fogli

Stern School of Business

Department of Economics

Kaufman Management Center

$44 \mathrm{~W} 4^{\text {th }}$ Street, Suite 7-140

New York, NY 10012

afogli@stern.nyu.edu 


\section{Introduction}

A woman's fertility is influenced by a large number of factors: her education, her wealth and income, where she lives, who she marries, etc., and, of course, her preferences over family size. The latter, as shown in Fernández and Fogli (2005), have a systematic component that depends upon the woman's heritage (i.e., her parents' country of origin). In that paper, we argued that a woman's heritage influences her work and fertility outcomes because different countries possess different norms and beliefs-i.e., different cultures-about the appropriate role for women in society, including how much (or whether) they should work when married and what is an ideal family size. These preferences and beliefs are transmitted by the family and hence where a woman's parents were born matters even if women share the same markets and institutions. We showed that, even after controlling for various characteristics of a woman, there is a quantitatively important effect of culture on a woman's work and fertility outcomes. Using past values of female labor force participation and total fertility rate (TFR) in the parents' country of origin to proxy for culture in the case of work and fertility, respectively, we showed that these variables enter positively and statistically significantly in explaining a woman's work and fertility outcomes in the US. ${ }^{1}$

An important question is whether our cultural variables are truly capturing the beliefs or norms in the country of heritage or whether they are instead proxying for direct personal experience. It could be argued, for example, that how much a woman's mother worked or the number of siblings a woman grew up with are what determines a woman's preferences in these areas, i.e., that culture is really simply personal experience that is intergenerationally transmitted (rather than also including, say, a component that is more akin to beliefs). Personal experience may differ from cultural beliefs (as transmitted by parents and perhaps neighborhood) for a variety of reasons. There may be various shocks that affect an individual's work experience or fertility, but that do not reflect that person's beliefs about woman's role nor about ideal family size. In this paper we wish to explore whether, once a woman's own family experience has been taken into account, culture still plays a role in determining fertility outcomes. ${ }^{2}$

\footnotetext{
${ }^{1}$ See also Blau (1992), Guinnane, Moehling, and O Grada (2002), and Gjerde and McCants (1995) for studies that point to country of origin mattering to fertility of immigrants.

${ }^{2}$ Fernández, Fogli, and Olivetti (2004) show that whether a man's mother works is a quantitative and statistically significant factor that helps explain whether his own wife works, even after controlling for many of his characteristics and those of his wife. That paper establishes, therefore, that "personal experience" matters. We argue that increased numbers of this new type of man (a man with a working mother) made it more attractive for women to invest in market skills and to work when married either because this type of man constituted a better partner for
} 
We use the General Social Survey (GSS) to study the fertility outcomes of US-born women as a function of their age, education, and various characteristics of their husbands. We use the number of siblings a woman has to reflect her own family experience and take lagged values of TFR in her country of ancestry to proxy for her culture. We find that both personal experience and culture matter to a woman's fertility. In particular, culture remains a statistically significant determinant of a woman's fertility even after controlling for her number of siblings. The effect of culture is quantitatively important. We find that a standard deviation increase in TFR is associated with an increase of 0.14 children, which is $50 \%$ of the variation in the number of children observed across ancestries in the US.

\section{Data Sets, Variables, and Sample Selection}

Our strategy here is similar to that in Fernández and Fogli (2005). In order to keep constant markets and institutions, we study the fertility outcomes of women who were born in and reside in the US, but who have different heritages (and hence presumably different cultures). As noted previously, we use the number of siblings a woman has to reflect her own family experience and TFR in her country of ancestry to proxy for her culture. ${ }^{3}$

To obtain our sample, we used the General Social Survey (GSS) which, in addition to providing data on the fertility behavior and ethnic origins of a respondent, also has information on a number of background characteristics including the number of siblings. ${ }^{4}$ Although the census would allow a larger sample size, it only provides information on the number of the individual's own siblings living in the household with the respondent. This is far too restrictive a definition as most individuals do not live with their siblings. We should note, however, that the definition of sibling in the GSS is not ideal as it includes stepbrothers and stepsisters. ${ }^{5}$

a married working woman, or because this type of man was more interested in marrying a woman who, like his mother, worked outside the household.

${ }^{3}$ The TFR is the average number of children a hypothetical cohort of women, from the ages of 15 to 49 , would have at the end of their reproductive period if they were subject during their whole lives to the fertility rates of a given period and if they were not subject to mortality. It is expressed as number of children per woman.

${ }^{4}$ The GSS is a series of cross sections that have been collected annually since 1972 (except for a few years) by the National Opinion Research Center. Each cross section contains about 1,500 observations, and respondents are asked about their demographic background, political and social attitudes, and labor market outcomes. Davis, Smith and Marsden (1999) describe the content and the sampling frame of the GSS.

${ }^{5}$ SIBS is the answer to the following question: "How many brothers and sisters did you have? Please count those born alive, but no longer living, as well as those alive now. Also include stepbrothers and stepsisters, and children 
Although the GSS does not provide direct information on the country of birth of a respondent's parents, it asks "From what countries or part of the world did your ancestors come?" We use the answer to this question to determine a woman's ancestry, though unfortunately we cannot distinguish second-generation Americans from those who have been in the US for longer. To obtain a sizeable sample, we use observations from the years 1977, 1978, 1980, and from 1982 to 1987.6

We construct our sample by including all married women of foreign ancestry born in the US and between 29 and 50 years of age. ${ }^{7}$ Note that these women's parents must have been in the US by 1927-1958, depending on the age of the woman and the survey year. Thus, on the one hand, it could be argued that TFR around 1930-1940 or even a decade or two earlier would best reflect the culture of the country of ancestry (though a large proportion of women must come from families who were in the US for several generations). On the other hand, one could argue that the values that parents and society transmit are best reflected in the behavior of the counterparts of these women in the country of ancestry in the early 80s. Data limitations, in any case, do not permit us to use years prior to 1950. Consequently, we choose TFR in 1950 in the country of ancestry as our benchmark cultural proxies but also explore 1960 and 1970 values as well. ${ }^{8}$

We conclude our selection by eliminating from our sample all women whose fathers were born in countries that became centrally planned economies around World War II. ${ }^{9}$ The rationale for doing this is that the parents of most women in our sample must have been in the US by 1940. Hence, these parents did not live through the profound transformations in the economies, institutions, and cultures that these countries experienced, and using data from the 1950s and later would thus not capture the correct culture for these individuals. We keep Russia in the sample, however, since the revolution was in 1917 and the parents may have been there for a substantial length of time thereafter. We are left with 1177 observations. Lastly, solely in order to be able to make meaningful comparisons across averages of women by country of ancestry, we

\footnotetext{
adopted by your parents".

${ }^{6} 1977$ is the first year in which people were asked where they were born.

${ }^{7}$ It should be noted that most individuals claim foreign ancestry: only approximately $8 \%$ of the sample (those in the categories of "American Indians" and "Americans") were eliminated by restricting the sample to women with foreign ancestry. We also exclude those individuals who gave answers that did not allow a country of ancestry to be assigned (e.g., "Africa").

${ }^{8}$ Cross-country data for 1950 TFR from the United Nations Demographic Yearbook.

${ }^{9}$ We eliminated Czechoslovakia, Hungary, Poland, Romania, Yugoslavia and Lithuania.
} 
also eliminated countries with fewer than 10 observations. ${ }^{10}$ Our final sample consists of 1145 women from 14 countries of ancestry: Canada, Denmark, UK, Finland, France, Germany, Ireland, Italy, Mexico, Netherlands, Norway, Russia, Spain and Sweden.

The summary statistics for the sample are presented in Table 1. The women in our sample are on average 38.3 years old, have 2.3 children, and 3.6 siblings. They and their husbands have on average 13 years of school and their parents around 10-11 years.

In Table 2 we report the summary statistics at the country level. The TFR in 1950 shows large variation across countries: from 6.9 children in Mexico to 2.2 in Germany. The average across countries is 3.0 with a standard deviation of 1.2. There is also a large dispersion in the number of siblings women have: from 7.3 in Mexico to 2.5 in Sweden with an average across countries of 3.8 and a standard deviation of 1.2. The correlation between the number of siblings and the $1950 \mathrm{TFR}$ is high (0.83). The number of children women have across ancestries in our sample does not vary as much: Mexican women again have the highest number of children (2.95) and French and Italian women the lowest (2.15). The average across countries is 2.46 with a standard deviation of 0.28 .

\section{Analysis and Results}

We estimate the following model:

$$
Z_{i s j t}=\beta_{0}+\beta_{1}^{\prime} X_{i}+\beta_{2} \widetilde{Y}_{i}+\beta_{2} \widetilde{Z}_{j}+f_{s}+\gamma_{t}+\varepsilon_{i s j t}
$$

where $Z_{i s j t}$ is the number of children born to woman $i$, who resides in region $s$, is of ancestry $j$, and is interviewed in year $t .{ }^{11}$ In $X_{i}$ we include a set of individual characteristics which varies with the specification considered, $f_{s}$ is a full set of dummies for the region of residence and $\gamma_{t}$ is the year of survey fixed effect. Our variables of interest are $\tilde{Y}_{i}$, the number of siblings woman $i$ has (SIBS), and $\widetilde{Z}_{j}$, which is the cultural proxy (TFR 1950), assigned by ancestry. Since this key variable on the right-hand side only varies by country of ancestry, all the standard errors we report are corrected for clustering at the country-of-ancestry level.

Tables $3 \mathrm{a}$ and $3 \mathrm{~b}$ present our main results. The regressions all include a full set of dummies for the woman's region of residence and year-of-interview fixed effects. The first column reports

\footnotetext{
${ }^{10}$ Austria, Greece, Japan, Puerto Rico, Switzerland, Portugal, and Belgium. Since our regressions are all run at the individual level, including these small numbers of observations does not affect our results.

${ }^{11}$ The regional variable includes the following 9 categories: New England, Middle Atlantic, East North Central, West North Central, South Atlantic, East South Central, West South Central, Mountain and Pacific.
} 
the results from regressing the number of children born to individual $i$ on the cultural proxy for fertility - TFR in 1950 assigned by country of ancestry. The coefficient on the cultural variable is positive and significant, indicating that women whose parents were born in countries where women had more children, tend to have more children themselves. In the second column, the number of siblings is substituted for the cultural proxy. The coefficient on this variable is also positive and significant, indicating that women from larger families tend to have more children. Introducing both variables in the regression in column (iii), we find both positive and statistically significant. Their magnitudes are somewhat smaller, indicating that there is a positive correlation between the two explanatory variables. ${ }^{12}$

There may be many reasons for the positive partial correlations above that have little to do with culture and family experience. In particular, our cultural proxy may be picking up characteristics of the women's parents that vary systematically across country of origin and affect a woman's human capital accumulation decision and, through that, her fertility behavior. Similarly, the number of siblings a woman has may not just be picking up the effect of one's own family experience in the process of preference formation about the ideal family size, but is likely to be correlated with a number of background factors which systematically differ across families and influence a woman's education acquisition.

Since we do not have enough background information about these women to directly rule out the possibility that our results are driven by systematic differences across families, we choose to control directly for a woman's level of education (an endogenous variable). By doing so, we are left with only the direct effect of culture and family experience on fertility.

The regression results from including a set of individual characteristics, in particular the woman's age, her age squared, and a set of dummy variables to capture her level of education (below high school [omitted], high school degree [High School], some college [Some College], and at least a college degree [College +$]$ ), are reported in columns (iv) through (vi). As expected, more educated women tend to have fewer children. The direct effects of culture and family experience remain positive and statistically significant, albeit both somewhat smaller in magnitude (especially the coefficient on SIBS), indicating that a woman's education tends to be negatively correlated with the TFR in her country of ancestry and her total number of siblings.

As a woman's fertility is likely to be influenced not only by her education but also by other family characteristics (e.g. wealth) and unobserved human capital, the last three columns of Table

\footnotetext{
${ }^{12}$ The correlation between SIBS and 1950 TFR at the individual level is 0.25 .
} 
3a report the results of including her mother's and father's levels of education to proxy for these. Interestingly, both variables are significant but of opposite signs: the father's education is positive whereas the mother's has a negative effect. One possible explanation for this is that the father's education is picking up family wealth whereas the mother's education is likely to be correlated with whether she worked or not (greater education is associated with a higher probability of work) which may then also influence the probability that her daughter works and her fertility choices. In all cases, both culture and family experience remain positive and significant.

To assess the quantitative impact of culture and family experience, note that a one standard deviation increase in $1950 \mathrm{TFR}$ is associated with a 0.14 increase in the number of children, whereas a one standard deviation increase in the number of siblings is associated with a 0.05 increase in children. As the standard deviation in the number of children across ethnicities is 0.28 , the differences across culture and family experience is accounting for a significant proportion of the variation across ethnicities.

Table 3b explores how the inclusion of the characteristics of a woman's husband affects our analysis. The first three columns present the results for a specification which includes the woman's characteristics and those of her husband's, namely, his age (and its square), education (in years), and total income (in units of $\$ 10,000$ ). In the case of the last variable, as the GSS does not report the income of the spouse but only that of the respondent and the family, we construct the husband's income by subtracting the woman's income from the family's total income. ${ }^{13}$ This variable unfortunately does not appear to be measured very well as it is insignificant in all specifications, whereas we know from our prior analysis using the 1970 US Census that husband's income enters positively and significantly in fertility analysis. ${ }^{14}$ Husband's education, on the other hand, enters negative and significant.

As can be seen in the table, culture and family experience both appear to play a quantitatively important role even after controlling for the husband's characteristics (though once parental education is entered, siblings are no longer significant): an increase of one standard deviation in

\footnotetext{
${ }^{13}$ Family income is total family income, from all sources in the previous year and before taxes. Respondent's income is labor earnings in the previous year before taxes and other deductions. Family and respondent's incomes on 1972-1993 surveys are in constant dollars (base $=1986$ ). These variables are based on categorical midpoints and imputations. For details see GSS Methodological Report No. 64. Since most of the women that declare themselves housewives, students or unemployed have missing income, and omitting them would bias our results, we recode these missing values with zero.

${ }^{14}$ See Fernández and Fogli (2005).
} 
1950 TFR is associated with an increase of 0.13 children, which is about $46 \%$ of the variation in number of children observed across ancestries. Similarly, an increase in SIBS of one standard deviation is associated with an increase of 0.06 children, which is about $21 \%$ of the same variation.

Overall, our results suggest that a woman's cultural heritage, as well as her own personal family experience, are distinct and quantitatively important factors in determining a woman's fertility decisions.

\section{Robustness}

The results we just described are robust to various changes in sample criteria and to the use of alternative cultural proxies. In particular, they are not driven by certain countries having large numbers of observations: we find similar results when exclude Germany or UK. We also find similar results when we use the 1960 level of TFR as our cultural proxy, which is not surprising since the correlation across countries between TFR in the 50s and 60s is around 0.96. Lastly, we also changed the sample by using a different decade. We repeated our analysis for women between the age of 29 and 50 in the years 1988-98 and obtained similar results.

\section{Conclusion}

Although economists have long stressed the importance of incentives for human behavior, it is only recently that there has been rigorous work showing that incentives operate within a framework given not only by markets, but also by institutions and, as a small but growing literature aims to show, by culture (or norms and beliefs). ${ }^{15}$ In this paper we aim to contribute to this literature by demonstrating that it is not only personal experience (as reflected in the number of siblings a woman has) that matters to a woman's fertility, but also that her culture (as embodied in the TFR in her country of ancestry) plays a role. Using several years of the GSS, we find that even after controlling for various characteristics and family background of a woman, both her own personal experience and her culture play a role in influencing her fertility.

\footnotetext{
${ }^{15}$ See, for example, Tabellini (2005) and Guiso, Sapienza, and Zingales (2003).
} 


\section{References}

[1] Blau, F. D. (1992), "The Fertility of Immigrant Women: Evidence from High Fertility Source Countries," in: Borjas, G. J., Freeman, R. (Eds.), Immigration and the Workforce: Economic Consequences for the United States and Source Areas, Chicago: University of Chicago Press, 93-133.

[2] Davis, J., T. Smith, and P. Marsden (1999), General Social Surveys, 1972-1998: Cumulative Codebook, Chicago: NORC.

[3] Fernández, R., and A. Fogli (2005), "Culture: An Empirical Investigation of Beliefs, Work, and Fertility," NBER Working Paper No. 11268.

[4] Fernández, R., A. Fogli, and C. Olivetti (2004), "Mothers and Sons: Preference Formation and Female Labor Force Dynamics," Quarterly Journal of Economics 119(4), 1249-1299.

[5] Gjerde, J., and A. McCants (1995), "Fertility, Marriage, and Culture: Demographic Processes Among Norwegian Immigrants to the Rural Middle West," The Journal of Economic History, $55(4), 860-888$.

[6] Guinnane, T., C. Moehling, and C. O Grada (2002), "The Fertility of the Irish in America in 1910," mimeo, Yale University.

[7] Guiso, L., P. Sapienza, and L. Zingales, (2003), "People's Opium? Religion and Economic Attitudes," Journal of Monetary Economics, 50(1), 225-282.

[8] Tabellini, G. (2005), "Culture and Institutions: Economic Development in the Regions of Europe," mimeo, IGIER, Bocconi University. 
Table 1: INDIVIDUAL SUMMARY STATISTICS

\begin{tabular}{lrrrr} 
Variable & Mean & Std. Dev. & Min & Max \\
\hline \hline Children & 2.35 & 1.51 & 0 & 8 \\
Siblings & 3.56 & 2.93 & 0 & 26 \\
Age & 38.27 & 6.34 & 29 & 50 \\
Education (yrs) & 13.05 & 2.34 & 3 & 20 \\
Husband's Age & 40.30 & 8.86 & 19 & 99 \\
Husband's Educ.(yrs) & 13.41 & 3.06 & 0 & 20 \\
Husband's Income & 3.42 & 2.64 & -0.73 & 16.26 \\
Father's Educ.(yrs) & 10.49 & 3.77 & 0 & 20 \\
Mother's Educ.(yrs) & 10.87 & 3.07 & 0 & 20 \\
\hline
\end{tabular}

There are 1145 women in our sample. The sample with parental education has 950 observations. Data are from the GSS 1977, $1978,1980,1982-87$. The sample consists of married women age 29-50, born in the U.S. with foreign ancestors. Income is measured in units of $\$ 10,000$.

Table 2: COUNTRY STATISTICS

\begin{tabular}{lrrrr} 
Country & Obs. & Children & Siblings & TFR 1950 \\
\hline \hline & & & & \\
Canada & 40 & 2.55 & 3.67 & 3.73 \\
Denmark & 14 & 2.86 & 3.86 & 2.54 \\
U.K. & 265 & 2.20 & 2.92 & 2.18 \\
Finland & 13 & 2.77 & 3.46 & 2.97 \\
France & 34 & 2.15 & 3.47 & 2.73 \\
Germany & 305 & 2.38 & 3.57 & 2.16 \\
Ireland & 224 & 2.38 & 3.99 & 3.38 \\
Italy & 91 & 2.15 & 2.81 & 2.32 \\
Mexico & 38 & 2.95 & 7.26 & 6.87 \\
Netherlands & 28 & 2.75 & 4.89 & 3.06 \\
Norway & 32 & 2.22 & 2.81 & 2.60 \\
Russia & 19 & 2.42 & 3.37 & 2.85 \\
Spain & 11 & 2.45 & 5.09 & 2.57 \\
Sweden & 31 & 2.19 & 2.48 & 2.21 \\
& & & & \\
Average & 81.79 & 2.46 & 3.83 & 3.01 \\
Std. Dev. & 102.24 & 0.28 & 1.23 & 1.20 \\
\hline
\end{tabular}


Table 3a: FERTILITY, CULTURE, AND SIBLINGS

Dependent variable is Children

\begin{tabular}{|c|c|c|c|c|c|c|c|c|c|}
\hline & (i) & (ii) & (iii) & (iv) & (v) & (vi) & (vii) & (viii) & (xi) \\
\hline TFR 1950 & $\begin{array}{l}0.166^{\star \star} \\
(0.025)\end{array}$ & & $\begin{array}{l}0.101^{\star *} \\
(0.026)\end{array}$ & $\begin{array}{l}0.117^{\star *} \\
(0.016)\end{array}$ & & $\begin{array}{l}0.097^{\star *} \\
(0.020)\end{array}$ & $\begin{array}{l}0.135^{\star *} \\
(0.036)\end{array}$ & & $\begin{array}{l}0.118^{\star} \\
(0.042)\end{array}$ \\
\hline SIBS & & $\begin{array}{l}0.093^{\star *} \\
(0.012)\end{array}$ & $\begin{array}{l}0.086^{\star \star} \\
(0.014)\end{array}$ & & $\begin{array}{l}0.044^{\star *} \\
(0.012)\end{array}$ & $\begin{array}{l}0.039^{*} \\
(0.014)\end{array}$ & & $\begin{array}{l}0.045^{\star} \\
(0.017)\end{array}$ & $\begin{array}{l}0.039+ \\
(0.019)\end{array}$ \\
\hline Age & & & & $\begin{array}{l}0.281^{*} \\
(0.098)\end{array}$ & $\begin{array}{l}0.304^{\star *} \\
(0.095)\end{array}$ & $\begin{array}{l}0.299 * * \\
(0.095)\end{array}$ & $\begin{array}{l}0.345^{\star \star} \\
(0.079)\end{array}$ & $\begin{array}{l}0.364^{\star *} \\
(0.083)\end{array}$ & $\begin{array}{l}0.359 * \star \\
(0.083)\end{array}$ \\
\hline Age sq & & & & $\begin{array}{c}-0.003+ \\
(0.001)\end{array}$ & $\begin{array}{l}-0.003^{*} \\
(0.001)\end{array}$ & $\begin{array}{l}-0.003^{*} \\
(0.001)\end{array}$ & $\begin{array}{c}-0.003^{\star \star} \\
(0.001)\end{array}$ & $\begin{array}{c}-0.004^{\star \star} \\
(0.001)\end{array}$ & $\begin{array}{c}-0.004^{\star \star} \\
(0.001)\end{array}$ \\
\hline High School & & & & $\begin{array}{c}-0.814^{\star \star} \\
(0.128)\end{array}$ & $\begin{array}{c}-0.764^{\star \star} \\
(0.122)\end{array}$ & $\begin{array}{c}-0.738^{\star \star} \\
(0.124)\end{array}$ & $\begin{array}{c}-0.629^{\star \star} \\
(0.152)\end{array}$ & $\begin{array}{c}-0.574^{\star \star} \\
(0.170)\end{array}$ & $\begin{array}{c}-0.564^{\star \star} \\
(0.162)\end{array}$ \\
\hline Some College & & & & $\begin{array}{c}-0.921^{\star *} \\
(0.063)\end{array}$ & $\begin{array}{c}-0.865^{\star \star} \\
(0.072)\end{array}$ & $\begin{array}{c}-0.822^{\star \star} \\
(0.055)\end{array}$ & $\begin{array}{c}-0.619^{\star *} \\
(0.181)\end{array}$ & $\begin{array}{l}-0.553^{\star} \\
(0.194)\end{array}$ & $\begin{array}{l}-0.532^{\star} \\
(0.178)\end{array}$ \\
\hline College + & & & & $\begin{array}{c}-1.362^{\star \star} \\
(0.100)\end{array}$ & $\begin{array}{c}-1.292^{\star \star} \\
(0.106)\end{array}$ & $\begin{array}{c}-1.250^{\star \star} \\
(0.108)\end{array}$ & $\begin{array}{c}-1.143^{\star \star} \\
(0.128)\end{array}$ & $\begin{array}{c}-1.071^{\star \star} \\
(0.147)\end{array}$ & $\begin{array}{c}-1.057^{\star \star} \\
(0.134)\end{array}$ \\
\hline $\begin{array}{l}\text { Mother's } \\
\text { Education }\end{array}$ & & & & & & & $\begin{array}{l}-0.060^{\star} \\
(0.024)\end{array}$ & $\begin{array}{c}-0.063^{\star \star} \\
(0.019)\end{array}$ & $\begin{array}{l}-0.056^{*} \\
(0.021)\end{array}$ \\
\hline $\begin{array}{l}\text { Father's } \\
\text { Education }\end{array}$ & & & & & & & $\begin{array}{l}0.027^{*} \\
(0.010)\end{array}$ & $\begin{array}{l}0.027^{*} \\
(0.010)\end{array}$ & $\begin{array}{l}0.028^{*} \\
(0.010)\end{array}$ \\
\hline $\begin{array}{l}\text { Obs. } \\
\text { Adj. R-sq }\end{array}$ & $\begin{array}{l}1145 \\
0.037\end{array}$ & $\begin{array}{l}1144 \\
0.060\end{array}$ & $\begin{array}{l}1144 \\
0.062\end{array}$ & $\begin{array}{l}1144 \\
0.203\end{array}$ & $\begin{array}{l}1143 \\
0.206\end{array}$ & $\begin{array}{l}1143 \\
0.208\end{array}$ & $\begin{array}{c}922 \\
0.223\end{array}$ & $\begin{array}{c}921 \\
0.225\end{array}$ & $\begin{array}{c}921 \\
0.229\end{array}$ \\
\hline
\end{tabular}


Table 3b: FERTILITY, CULTURE, AND SIBLINGS

Dependent variable is Children

\begin{tabular}{|c|c|c|c|c|c|c|}
\hline & (i) & (ii) & (iii) & (iv) & (v) & (vi) \\
\hline TFR 1950 & $\begin{array}{l}0.111^{\star *} \\
(0.013)\end{array}$ & & $\begin{array}{l}0.089 \star \star \\
(0.021)\end{array}$ & $\begin{array}{l}0.115^{\star} \\
(0.045)\end{array}$ & & $\begin{array}{l}0.101+ \\
(0.053)\end{array}$ \\
\hline SIBS & & $\begin{array}{l}0.050^{*} \\
(0.017)\end{array}$ & $\begin{array}{l}0.044^{\star} \\
(0.019)\end{array}$ & & $\begin{array}{c}0.039 \\
(0.023)\end{array}$ & $\begin{array}{c}0.033 \\
(0.025)\end{array}$ \\
\hline Age & $\begin{array}{l}0.332^{\star} \\
(0.128)\end{array}$ & $\begin{array}{l}0.362^{*} \\
(0.128)\end{array}$ & $\begin{array}{l}0.355^{\star} \\
(0.127)\end{array}$ & $\begin{array}{l}0.370^{\star \star} \\
(0.090)\end{array}$ & $\begin{array}{l}0.390^{\star \star} \\
(0.096)\end{array}$ & $\begin{array}{l}0.384^{\star \star} \\
(0.096)\end{array}$ \\
\hline Age sq & $\begin{array}{c}-0.003+ \\
(0.002)\end{array}$ & $\begin{array}{l}-0.004^{\star} \\
(0.002)\end{array}$ & $\begin{array}{l}-0.004^{*} \\
(0.002)\end{array}$ & $\begin{array}{l}-0.004^{\star \star} \\
(0.001)\end{array}$ & $\begin{array}{c}-0.004^{\star *} \\
(0.001)\end{array}$ & $\begin{array}{c}-0.004^{\star *} \\
(0.001)\end{array}$ \\
\hline High School & $\begin{array}{c}-0.799 \star \star \\
(0.125)\end{array}$ & $\begin{array}{c}-0.762^{\star \star} \\
(0.127)\end{array}$ & $\begin{array}{c}-0.737^{\star \star} \\
(0.124)\end{array}$ & $\begin{array}{c}-0.582^{\star \star} \\
(0.190)\end{array}$ & $\begin{array}{l}-0.547^{\star} \\
(0.189)\end{array}$ & $\begin{array}{l}-0.537^{*} \\
(0.181)\end{array}$ \\
\hline Some College & $\begin{array}{c}-0.839 * * \\
(0.094)\end{array}$ & $\begin{array}{c}-0.801^{\star *} \\
(0.094)\end{array}$ & $\begin{array}{c}-0.765^{\star \star} \\
(0.079)\end{array}$ & $\begin{array}{l}-0.531^{\star} \\
(0.221)\end{array}$ & $\begin{array}{l}-0.488^{\star} \\
(0.220)\end{array}$ & $\begin{array}{l}-0.472^{*} \\
(0.206)\end{array}$ \\
\hline College + & $\begin{array}{c}-1.272^{\star \star} \\
(0.127)\end{array}$ & $\begin{array}{c}-1.228^{\star *} \\
(0.122)\end{array}$ & $\begin{array}{c}-1.198^{\star *} \\
(0.117)\end{array}$ & $\begin{array}{c}-1.007^{\star *} \\
(0.202)\end{array}$ & $\begin{array}{c}-0.967^{\star \star} \\
(0.192)\end{array}$ & $\begin{array}{c}-0.962^{\star \star} \\
(0.181)\end{array}$ \\
\hline $\begin{array}{l}\text { Husband's } \\
\text { Education (yrs) }\end{array}$ & $\begin{array}{c}-0.032^{\star *} \\
(0.010)\end{array}$ & $\begin{array}{l}-0.026^{*} \\
(0.011)\end{array}$ & $\begin{array}{l}-0.024^{*} \\
(0.010)\end{array}$ & $\begin{array}{c}-0.037^{\star \star} \\
(0.009)\end{array}$ & $\begin{array}{l}-0.035^{\star} \\
(0.012)\end{array}$ & $\begin{array}{l}-0.032^{*} \\
(0.011)\end{array}$ \\
\hline $\begin{array}{l}\text { Husband's } \\
\text { Total Income }\end{array}$ & $\begin{array}{c}0.008 \\
(0.014)\end{array}$ & $\begin{array}{c}0.009 \\
(0.014)\end{array}$ & $\begin{array}{c}0.009 \\
(0.014)\end{array}$ & $\begin{array}{l}-0.001 \\
(0.013)\end{array}$ & $\begin{array}{c}0.000 \\
(0.012)\end{array}$ & $\begin{array}{l}-0.001 \\
(0.013)\end{array}$ \\
\hline $\begin{array}{l}\text { Mother's } \\
\text { Education }\end{array}$ & & & & $\begin{array}{l}-0.063^{\star} \\
(0.024)\end{array}$ & $\begin{array}{c}-0.066^{\star *} \\
(0.021)\end{array}$ & $\begin{array}{l}-0.060 * \\
(0.022)\end{array}$ \\
\hline $\begin{array}{l}\text { Father's } \\
\text { Education }\end{array}$ & & & & $\begin{array}{l}0.028^{\star *} \\
(0.007)\end{array}$ & $\begin{array}{l}0.028^{\star \star} \\
(0.007)\end{array}$ & $\begin{array}{l}0.028^{\star \star} \\
(0.007)\end{array}$ \\
\hline $\begin{array}{l}\text { Obs. } \\
\text { Adj. R-sq }\end{array}$ & $\begin{array}{l}1033 \\
0.206\end{array}$ & $\begin{array}{l}1032 \\
0.211\end{array}$ & $\begin{array}{l}1032 \\
0.212\end{array}$ & $\begin{array}{c}845 \\
0.222\end{array}$ & $\begin{array}{c}844 \\
0.225\end{array}$ & $\begin{array}{c}844 \\
0.227\end{array}$ \\
\hline
\end{tabular}

